\title{
SENSASI DAN PERSEPSI PADA PSIKOLOGI KOMUNIKASI
}

\author{
Vivi Novinggi
}

\begin{abstract}
Abstrak
Allah swt menganugerahkan alat indera kepada makhluk-Nya untuk mengetahui segala sesuatu di luar dirinya. Melalui alat indera manusia dan hewan bisa menjaga dirinya dan mempertahankan kehidupannya. Di dalam psikologi, dikenal dua istilah pemrosesan informasi yang diterima dari pengamatan, yaitu sensasi dan persepsi. Dalam arti sempit kedua istilah ini tidak dibedakan karena kedua fungsi ini merupakan dua proses yang melibatkan pengamatan. Tetapi, secara fungsional kedua fungsi psikis ini sangat berbeda.

Beberapa bentuk emosi bisa memengaruhi persepsi. Misalkan seorang anak yang takut berada di kamar yang gelap akan mempersepsi kamar tersebut banyak sesuatu yang menakutkan. Kecintaan kita pada seseorang pun menjadikan diri kita lupa untuk mengetahui kekurangan yang ada pada orang yang kita cintai. Begitu juga dengan kebencian pada seseorang menyebabkan kita hanya memerhatikan kejelekannya saja tanpa melihat kebaikannya. Rasulullah saw mengisyaratkan bahwa semua dorongan dan emosi yang terdapat dalam diri kita dapat menghalangi persepsi dan pikiran secara benar. Sabda Rasulullah saw yang artinya: Cinta kepada dunia merupakan pangkal setiap kesalahan dan cintamu kepada sesuatu akan menjadikan dirimu buta dan tuli. Diriwayatkan oleh Anas ra. Hadits ini mengisyaratkan bahwa kecintaan kepada dunia dapat memperlambat cara berpikir yang benar dan menghalangi persepsi kita secara tepat. Mencintai sesuatu secara berlebihan dapat menyebabkan buta dan tuli karena panca indera dan cara berpikir cenderung akan keliru.

Dikehidupan kita sehari-hari kita selalu menggunakan indra kita untuk mengetahui apa yang kita rasakan, tanpa alat-alat indra kita tidak bisa merasakan kehidupan di dunia ini. Dalam makalah ini akan membahas sensasi dan persepsi, seperti yang kita ketahui didalam sensasi indra kita ada dua stimuli (rangsang), yang pertama stimuli eksternal dan stimuli internal. kemudian bagaimana sensasi dalam dimensi pengindraan dan ambang pengindraan. dalam makalah ini juga akan membahas bagaimana alat-alat indra kita merasakan sesuatu atau rangsang. Seperti alat indra penglihatan, pendengaran, pengecapan, penciuman dan perasa. Dan kemudian dalam persepsi, kita ketahui apa itu persepsi setelah kita mengetahui sensasi. Dikarnakan sensasi mempengaruhi persepsi.

Persepsi dalam pandangan Islam adalah suatu proses kognitif yang dialami individu dalam memahami informasi baik melalui panca indera, seperti mata untuk melihat, telinga untuk mendengar, hidung untuk penciuman, hati untuk merasakan, dan pemahaman dengan indera mata maupun pemahaman dengan hati dan akal. Ada faktor-faktor yang mempengaruhi persepsi, yaitu faktor perhatian yang meliputi faktor eksternal dan internal, faktor fungsional dan faktor struktural.
\end{abstract}

\section{Kata kunci: Sensasi, persepsi, Psikologi Komunikasi}

\section{A. Sensasi}

Tahap paling awal dalam penerima informasi adalah sensasi. Sensasi berasal dari kata "sense", artinya alat pengindraan, yang menghubungkan organisme dengan lingkungannya. Bila alat-alat indera mengubah informasi menjadi implus-implus saraf dengan "bahasa" yang dipahami oleh otak maka terjadilah proses sensasi, kata Dennis Coon (1977:79). 
"sensasi adalah pengalaman elementer yang segera, yang tidak memerlukan penguraian verbal, simbolis, atau konseptual, dan terutama sekali berhubungan dengan kegiatan alat indera," tulis bunyamin B. Wolman (1973:343).

Tulisan dalam buku Jalaluddin Rahmad tidak ada satupun menggunakan pemahaman Islam. Menurut penulis terjadinya proses sensasi ini disebabkan ketika alat pengindra kita merangsang sesuatu yang dirasakan atau dilihat kemudian dipahami di otak kita apa yang dirasakan atau dilihat dan didengar. Inilah yang dinamakan sensasi. Pemakalah telah menulis pemahaman dalam islam Seperti dibawah ini ada beberapa ayat yang menyinggung tentang sensasi.

Allah berfirman dalam surat An-Nahl ayat 78 yang berbunyi:

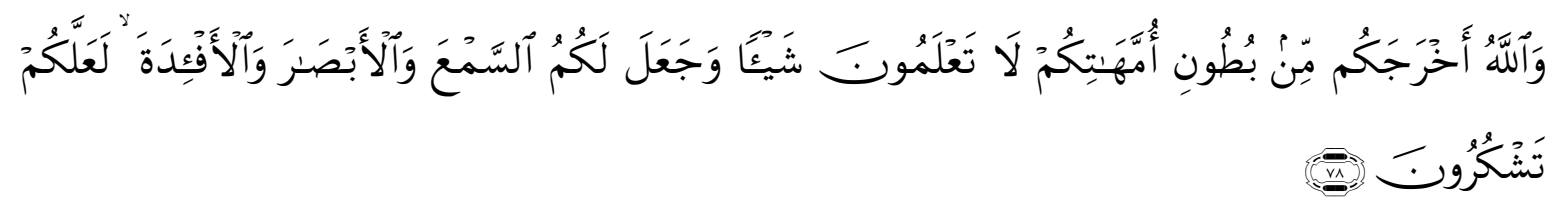

Artinya : Dan Allah mengeluarkan kamu dari perut ibumu dalam keadaan tidak mengetahui sesuatupun, dan dia memberi kamu pendengaran, penglihatan dan hati, agar kamu bersyukur.

Dan kemudian surat Sajadah ayat 9 Allah berfirman:

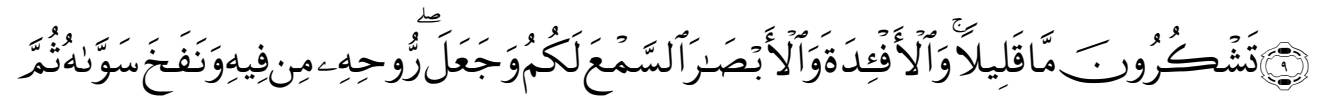

"Kemudian Ia membentuk rupanya, dan meniupkan ke dalamnya sebagian rohNya, dan Ia memberi kamu pendengaran, penglihatan dan hati nurani (daya pengertian); sedikit kali kamu mau bersyukur.” Abdullah Yusuf Ali,2006:1060)

Ayat tersebut memberikan gambaran bahwa manusia dilahirkan dengan alat indera untuk manusia sehingga manusia dapat merasa atas apa yang terjadi padanya dari pengaruh-pengaruh luar yang baru dan mengandung perasaan-perasaan yang berbeda sifatnya antara saudara dengan yang lainnya. Dengan alat indera tersebut, manusia akan mengenali lingkungannya dan hidup di dalam lingkungan tersebut.

Sensasi adalah proses menangkap stimuli. Ketika seorang muballigh tampil ke mimbar, maka stimuli yang ditangkap hadirin mula-mula adalah sosok tubuhnya oleh indera mata), kemudian setelah berpidato, orang menangkap stimuli suaranya (oleh indra pendengaran), dan bagi yang dekat duduknya akan menerima stimuli aromanya (oleh indra penciuman) dan bagi yang bersalaman akan menangkap stimuli halus atau dingin atau hangat 
tangannya (oleh indra peraba). Jadi apa saja yang menyentuh alat indra disebut stimuli. (Achmad Mubarok,2008:108)

Jadi stimuli itu adalah rangsangan. alat indera kita menangkap satu persatu dari apa yang dirasa atau dilihat dan didengar. Sehingga apa yang kita rasakan atau dilihat maka kita mengetahui karakter orang tersebut yang kita lihat atau dirasa dan didengar. Kita bisa menggunakan mata,peraba dan pendengaran untuk mengetahui hal tersebut.

Dalam proses kerjanya sistem sensasi ini dikerjakan dalam sebuah proses mendeteksi sejumlah rangsang sebagai bahan informasi yang diubah menjadi implus saraf dan dikirim ke otak melalui benang-benang saraf. Jadi secara sederhana proses sensasi ini diartikan sebagai alat penerima (reseptor) sejumlah rangsang yang akan diteruskan ke otak yang kemudian akan menyeleksi rangsang yang diterima tersebut. (Abdul Rahman Shaleh, 2008:97-98)

Dalam buku Psikologi yang ditulis oleh Abdul Rahman halaman 97 sampai 98 Menurut pemahaman pemakalah, bukan proses sensasi ini yang menjadi reseptor atau penerima pesan tetapi sensasi. Jika proses sensasi, ini lebih mengarah bagaimana langkah-langkah terjadinya sensasi.

Apa saja yang menyentuh alat indera dari dalam atau dari luar disebut stimuli. Saat ini kita sedang mengajar diruangan kelas (stimuli eksternal), padahal pikiran kita sedang diganggu oleh perjanjian sewa rumah yang habis waktu hari ini yang sudah 3 bulan menunggak. (stimuli internal). Anda serentak menerima dua macam stimuli. Alat indera anda segera mengubah stimuli ini menjadi energi saraf untuk disampaikan ke otak melalui transduksi. Agar dapat diterima pada alat indera, stimuli harus cukup kuat. Batas minimal intensitas stimuli disebut ambang mutlak. (Jalaluddin Rahmat, 2006:50)

Jadi alat indera kita ada dari dalam dan luar. Yang namun dalam penerimaan rangsangan tersebut yang sekaligus dua rangsangan yang diterima, maka ambang mutlak ini harus cukup kuat. Maksut dari ambang mutlak ini kuat atau lemahnya alat indera kita dalam menerima rangsangan tersebut.

\section{Dimensi pengindraan}

Pengalaman indirawi: pengalaman indrawi (sensori experience) tergantung pada saat diterimanya rangsang sehingga kita mempunyai pengalaman indrawi yang dapat kita katakan kuat lelah, lama sebentar, kasar halus, panas dingin dan lain-lain. Sifat-sifat seperti inilah yang disebut dimensi pengindraan. Ada empat dimensi pengindraan, yaitu:

a. Intensitas: kuat lemahnya pengindraan suatu rangsang tertentu. Kita dapat membedakan cahaya kuat dan lemah. Ini berlaku pada semua alat indra. 
b. Ekstentitas: penghayatan terhadap tebal tipis, luas sempit, besar kecil, dan lain-lain.

c. Lamanya: pengindraan dapat berlangsung lama atau sebentar.

d. Kualitas: kita dapat membedakan kualitas rangsang, misalnya, pendakwah yang bagus dan tidak.

\section{Ambang Pengindraan}

Ambang dalam pengindraan berarti intensitas suatu rangsang tertentu agar dapat disadari apa yang dirangsangnya. Persoalan ini juga berhubungan dengan sejauh mana indra dapat membedakan intensitas dua buah rangsang atau lebih.

a) Ambang perangsang absolut, yaitu: intensitas rangsang terkecil yang masih dapat menimbulkan pengindraan.

\begin{tabular}{|c|c|}
\hline INDRA & AMBANG PERANGSANG ABSOLUT \\
\hline Penglihatan & $\begin{array}{l}\text { Nyala api lilin dilihat dari jarak } 30 \text { mil pada waktu } \\
\text { malam hari yang cerah. }\end{array}$ \\
\hline Pendengaran & $\begin{array}{l}\text { Bunyi detak jam tangan dalam suasana sepi dari jarak } \\
\pm 6 \text { meter. }\end{array}$ \\
\hline Pengecapan & Satu sendok teh gula dalam 7 liter air. \\
\hline Penciuman & $\begin{array}{l}\text { Setetes minyak wangi yang baunya beredar dalam } \\
\text { udara dengan volume sebesar sebuah apartemen } \\
\text { dengan tiga kamar ( } \pm 50 \text { meter). }\end{array}$ \\
\hline perasa & $\begin{array}{l}\text { Sebuah sayap lalat yang dijatuhkan ke atas tengkuk } \\
\text { dari jarak } 1 \text { meter. }\end{array}$ \\
\hline
\end{tabular}


b) Ambang perbedaan: yaitu, perbedaan intensitas rangsangan terkecil yang dapat dibedakan oleh alat indra. Artinya, membedakan dua intensitas rangsang, dibutuhkan energi minumum.

c) Tinggi rangsang: pertambanhan intensitas rangsang akan diikuti oleh pengindraan intensitas pengindraan sampai mencapai maksimum (intensitas pengindraan tidak bisa ditambah lagi), akibatnya penambahan intensitas rangsang tidak dapat dibedakan lagi.

d) Penyesuaian sensoris: terjadi dengan beberapa cara. Berkurangnya kepekaan indra (bila sinar bertambah) disebut penyesuaian sensoris negatif kepekaan indra bertambah bila makin gelap disebut penyesuaian sensoris positif. Penyesuaian juga bisa terjadi dengan cara penggeseran titik sentral. Bila kita menyentuh benda yang suhunya sama dengan tubuh kita, kita tidak merasa apa-apa, inilah titik sentral. Benda yang bertemperatur lebih rendah dari tubuh kita akan dihayati sebagai dingin dan yang lebih tinggi dihayati sebagai lebih panas.

Jadi seseorang itu ada yang kuat stimulinya, sehingga hal yang terkecilpun bisa dirasakannya. Ini tidak ada disemua orang yang dapat merasakannya. Anak umur 6 tahun bisa menghafal Al-Qur'an sebanyak 30 juz, nah ini dalam psikologi sulit menerima stimuli yang seperti ini. Secara agama ini adalah bentuk dari kebesaran Allah SWT. Termasuk juga ilmu Laduni.

\section{B. Persepsi}

Persepsi adalah proses memberi makna pada sensasi sehingga manusia memperoleh pengetahuan baru. Ketika anda melihat muballigh kondang, Zainuddin MZ datang dengan mengendarai mobil mewah, kemudian anda mendengar pidatonya yang menarik, maka sensasi melalui penglihatan dan pendengaran anda itu berubah menjadi informasi bahwa muballigh ibukota itu hebat, anda mempersepsi Zainuddin MZ sebagai "hebat". Ketika anda berjumpa dengan saudara seperguruan Zainuddin, anda mempersepsi bahwa ia juga tak jauh berbeda dengan kehebatan Zainuddin, tetapi ketika anda bagaimana mendengar pidato temannya itu, ternyata anda tidak menjumpai kehebatannya. Dalam hal ini anda keliru dalam mempersepsi. Tetapi ketika anda mendengar mubaligh mengatakan silat padahal ia mengatakan shalat maka anda keliru dalam sensasi. (Achmad Mubarok,2009:49)

Dalam buku Psikologi Dakwah yang di tulis oleh Achmad Mubarok tidak ada ayat AlQur'an dan dalil-dalil serta menurut ulama-ulama yang menjelaskan tentang Persepsi. 
Hanya saja beliau hanya menulis contoh-contoh yang bernuansa ke Islaman. Di pembahasan Persepsi pemakalah ada menulis ayat Al-Qur'an yang mengenai Persepsi.

Prosespersepsi didahului dengan proses penerimaan stimulus pada reseptor, yaitu indera. Fungsi indera manusia sendiri tidak langsung berfungsi setelah ia lahir, akan tetapi ia akan berfungsi sejalan dengan perkembangan fisiknya. Sehingga ia dapat merasa atas apa yang terjadi padanya dari pengaruh-pengaruh eksternal yang baru dan mengandung perasaan-perasaan yang akhirnya membentuk persepsi dan pengetahuannya terhadap alam luar.

Ada beberapa ayat di bawah ini mewakili tentang panca indera yang berperan dalam proses persepsi, antara lain:

- Penglihatan
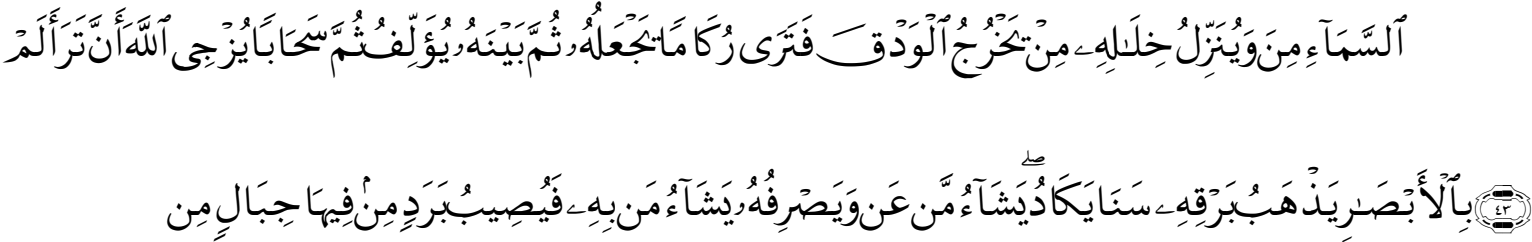

"Tidaklah kamu melihat bahwa Allah membuat awan mengarak perlahan, kemudian mempertemukannya kemudian menghimpunnya bersusun-susun, lalu kau lihat hujan turun dari sela selanya. Dan dia menurun kan dari langit bergunung-gunung gumpalan awan yang mengandung butiran salju; maka ditimpakan-Nya dari siapa saja yang ia kehendaki; kilauan kilat-Nya hampir-hampir menyapu penglihatan." (Abdullah Yusuf Ali, 2008:888) (QS. An-Nuur ayat: 43)

- Pendengaran

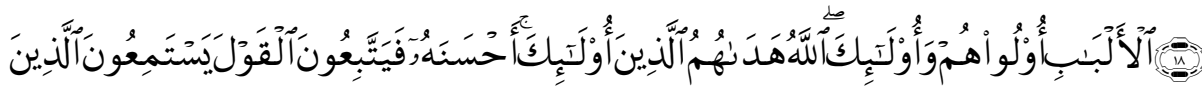

"mereka yang mendengarkan Perkataan, dan mengikuti yang terbaik diantaranya, maka mereka itulah yang mendapat bimbingan Allah, dan mereka itulah orang yang arif." (Abdullah Yusuf Ali, 2008:201) (QS. Az-Zumar ayat: 18)

- Penciuman

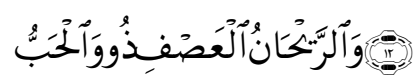

"Dan biji-bijian yang berkulit dan bunga-bunga yang harum baunya." (Abdullah Yusuf Ali, 2008:403) (QS. ArRahman ayat: 12) 
Dalam Q.S. Yusuf ayat: 94 Allah berfirman:

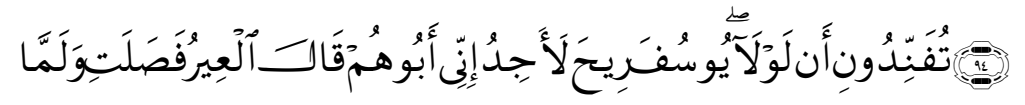

Tatkala kafilah itu telah ke luar (dari negeri Mesir) berkata ayah mereka: "Sesungguhnya aku mencium bau Yusuf, Sekiranya kamu tidak menuduhku lemah akal (tentu kamu membenarkan aku). (Abdullah Yusuf Ali, 2008:574)”

Ini terjadi ketika kendaraan yang membawa pakaian Nabi Yusuf as dari Mesir yang tengah menuju ke sebuah negeri dimana Nabi Ya ${ }^{e e} q u b$ as tinggal.

- Perasaan

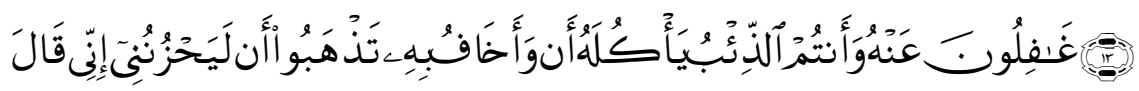

Berkata Ya'qub: "Sesungguhnya kepergian kamu bersama Yusuf Amat menyedihkanku dan aku khawatir kalau-kalau dia dimakan serigala, sedang kamu lengah dari padanya." (Ahmad Mustafa Al-Maragi,1993:234) (QS:Yusuf ayat 13)

\section{Faktor yang Mempengaruhi Persepsi}

Persepsi kita keliru bisa berbeda-beda karena dipengaruhi oleh berbagai faktor, personal, situasional, fungsional, dan struktural. Di antara faktor yang besar pengaruhnya dalam mempersepsi sesuatu adalah perhatian, konsep fungsional dan konsep struktural. (Ahmad Mustafa Al-Maragi,1993:109)

\section{a. Faktor Perhatian}

Perhatian adalah proses mental di mana kesadaran terhadap suatu stimuli lebih menonjol, dan pada saat yang sama terhadap stimuli yang lain melemah. Sebagai contoh, ketika pertunjukan film di dalam gedung bioskop dimulai, maka kesadaran penonton terhadap gambar dilayar pasti lebih menonjol, sementara kesadaran terhadap teman disamping, apalagi terhadap penonton lain di belakangnya menjadi melemah. Perhatian penonton lebih ditujukan kepada gambar dilayar, sementara stimuli lain tidak menarik perhatiannya lagi.

Ada beberapa FaktorEksternal dan internal dalam penarik perhatiandapat dibagi sebagai berikut:

1. Faktor Eksternal

a) Prinsip Gerakan

Secara psikologis, manusia tertarik kepada apa saja yang bergerak. Benda kecil yang bergerak-gerak pasti lebih menarik perhatiannya dibandingkan benda 
besar yang diam. Apabila seseorang berdiri ditengah jalan Thamrin, jika tidak ada satupun mobil yang lewat dan tidak ada seorang pun selain dia, maka ada seekor kucing kecil yang bergerak melewati jalan protokol lebih menarik perhatian dibanding gedung pencakar langit di kiri dan di kanan.

Dalam hadits yang diriwayatkan oleh Anas ra, terdapat peristiwa persepsi eksternal. Rasulullah saw bisa melihat para sahabatnya dari belakang punggungnya. "Wahai manusia, sesungguhnya aku adalah imam kalian semua. Janganlah kalian mendahuluiku ketika ruku, sujud, berdiri dan pergi. Karena sesungguhnya aku melihat kalian semua, baik kalian berada di depan mataku atau kalian berada di belakangku.” Penglihatan seseorang terhadap sesuatu yang berada di belakang dirinya merupakan jenis persepsi eksternal karena mata sesungguhnya tidak dapat menangkap pengaruh apapun yang wujudnya berada di belakang dirinya.

b) Prinsip kontras

Suara kertas di tengah keheningan, sorot lampu di tengah kegelapan warna merah di latar belakang putih pasti menarik perhatiannya. Maka dari itu pidato di tengah kerumunan orang banyak memerlukan pengeras suara mubaligh menjadi kontras mengalahkan suara obrolan orang banyak.

Begitu juga mimbar harus lebih tinggi dibandingkan para audien, dan cahaya lampu di panggung acara harus dibuat lebih terang dibandingkan dengan ruangan lain sehingga para hadirin perhatiannya terpusat ketempat itu. Demikian juga dalam memilih warna tulisan pada spanduk atau dekor, harus warna yang kontras dengan warna kain yang menjadi latar belakangnya.

c) Prinsip Kebaruan

Segala sesuatu yang baru sudah pasti menarik perhatian manusia. Cotohnya seperti barang baru, model baru lagu baru, suasana baru, orang baru dan juga ide-ide baru. Hal ini disebabkan di dalamnya mempunyai nilai: hebat, luar biasa, aneh, berbeda dengan yang biasa. Jika seseorang mempunyai istri baru yang lebih menarik dibandingkan dengan istri yang lama, ini hal yang biasa. Jika kita kaitkan dengan dakwah, seorang $d a^{\prime} i$ harus dapat tampil mengetegahkan hal yang baru, yang berbeda dan jika mungkin yang hebat, untuk dapat menarik perhatian mad'u. Kebaruan sesuatu tidak mesti bersifat 
keseluruhan, tapi bisa juga barang lama kemasan baru. Bahan lama modelnya baru, pendapat lama ilustrasinya baru.

Dalam buku Psikologi Dakwah yang ditulis oleh Achmad mubarok, Jika seseorang mempunyai istri baru yang lebih menarik dibandingkan dengan istri yang lama, ini hal yang biasa. Menurut pemakalah jika dikaitkan dengan istri baru maka ini menjadi faktor perhatian juga. Karena hal yang baru itu belum di rasakannya atau digunakannya, maka lelaki itu bisa menoleh perhatiannya.

d) Prinsip perulangan

Pada tahun 1974, seorang wanita, guru Bahasa Inggris, beragama Katolik, tinggal dan bekerja dikomplek pendidikan Katolik di belakang Gereja Katedral Jakarta mengatakan memeluk Islam. Menurut mengakuannya, ketertarikan dengan agama Islam dimulai saat mendengar adzan di masjid Istiqlal yang berhadapan dengan gereja itu.

Pada awalnya sangat terganggu dengan suara adzan yang dipancarkan di menara masjid dengan pengeras suara yang berulang-ulang setiap harinya. Dan kemudian ia tak dapat melarang adzan dan tidak dapat pula menutup telinganya, maka suara adzan setiap hari terdengar. Karena berulang-ulangnya suara adzan itu terdengar maka lama kelamaan suara itu menjadi akrap di telinganya, dan lama kelamaan suara adzan terdengar indah dan pada akhirnya selalu ditunggu dan kemudian tergiang-ngiang di telinganya. Suara adzan yang terdengar berulang-ulang itu yang menyebabkan ia mengucap dua kalimah syahadat,walaupun pekerjaannya hilang.

Jika kita lihat dari psikologis, perulangan mendengar, perulangan perjumpaan dan perulangan "merasa" dapat menjadi faktor penarik perhatian. Contoh yang sangat sering kita jumpai dan sangat efektif yaitu iklan produk yang ditayangkan berulang-ulang di televisi dalam menarik perhatian pembeli. Achmad Mubarok, 2008:110-113)

\section{Faktor Internal}

a) Faktor Biologis

Orang lapar cendrung tertarik perhatiannya kepada makanan, orang haus lebih tertarik kepada minuman, sedang orang yang sedang kelelahan lebih tertarik perhatiannya kepada kursi atau tempat tidur.

b) Faktor Sosiopsikologis 
Berikan sebuah foto yang menggambarkan kerumunan orang banyak disebuah jalan sempit. Tanyakan apa yang mereka lihat. Setiap orang akan melaporkan hal yang berbeda. Tetapi sseorangpun tidak akan dapat melaporkan berapa orang terdapat pada gambar itu, kecuali kalau sebelum melihat foto mereka memperoleh pertantaan itu. (Jalaluddin Rahmat, 2007:54)

\section{Faktor Fungsional}

Faktor fungsional berasal dari kebutuhan. Pengalaman masa lalu dan hal-hal lain yang termasuk apa yang kita sebut sebagai faktor personal. Yang menentukan persepsi bukan jenis atau bentuk stimuli, tetapi karakteristik orang yang memberikan respons pada stimuli itu. (Jalaluddin Rahmat, 2007:55-56) Yang mempengaruhi persepsi yaitu faktor fungsional. Antara lain faktor kebutuhan, kesiapan mental, suasana emosional dan latar belakang budaya.contohnya kita katakan seperti:

- Dua orang mahasiswa sedang duduk di kantin, yang satu lapar dan yang lain haus. Yang pertama cendrung mempersepsi isi etalase kantin sebagai nasi dan daging, sedangkan yang satunya cendrung mempersepsi sprit dan Coca Cola.

- Uang ribuan di persepsi kecil oleh kelompok anak orang kaya, tapi dipersepsi besar sekali oleh kelompok anak pengangguran. (Achmad Mubarok, 2008:113-114)

Suasana mental juga mempengaruhi persepsi. Ketika perang teluk berlangsung, sebuah mobil bak terbuka yang membawa tiang listrik dipinggiran kota Basrah Irak di persepsi oleh pilot pesawat tempur Amerika sebagai tank irak, sehingga di jatuhi bom. Suasana mental, yakni suasana perang begitu besar pegaruhnya terhadap sang pilot dalam mempersepsi, padahal peralatan pesawat tempur Amerika dikenal sangat canggih untuk hanya sekedar membedakan tiang listrik dengan laras meriam tank.

mengenai faktor rujukan, didalam kegiatan komunikasi, kerangka rujukan mempengaruhi bagaimana orang memberi makna pada pesan yang diterimanya. Berbicara tentang fluor albus, adnexitis, dysmenorhhae, atau kanker cerviks di muka ahli komunikasi, tidak akan menimbulkan pengertian apa-apa. Mereka tidak memiliki kerangka rujukan untuk memahami istilah-istilah kedokteran tersebut. Begitunya sebaliknya, mahasiswa kedokteran akan sulit memahami tentang teoriteori komunikasi, apabila mereka tidak memiliki latar belakang pendidikan ilmu komunikasi. (Jalaluddin Rahmat, 2007:58)

\section{Faktor Struktural}

Menurut teori Gestalt bila seseorang mempersepsikan sesuatu, maka ia mempersepsinya dengan keseluruhan, jadi bukan bagian-bagiannya saja. Contoh kita 
katakan saja, kita melihat wajah yang cantik seorang wanita, maka yang kita persepsi bukan hanya wajahnya saja, tetapi keseluruhan tubuh dari gadis tersebut, kerana wajah itu hanya bagian saja dari struktur tubuh. (Achmad Mubarok, 2007:114-115)

Gestalt teori yang dikembangkan di Jerman. Teori Gestalt ini adalah sebuah teori, yaitu teori Bentuk. Ini bisa digunakan ketika seseorang menilai orang lain melalui bentuk orangnya/perilakunya.

Jadi struktur ini, jika di pandang dengan orang yang berbeda namun objeknya sama, maka persepsi orang itu berbeda-beda. Contoh kita katakan seperti seorang dosen mempersepsi buku dan beras sebagai kebutuhan pokok, kerena bagi seorang dosen, keduanya memang sama-sama dibutuhkan, tetapi jika seorang pengusaha mempersepsi buku dan beras, maka persepsinya itu sangat berbeda juah, dikarnakan buku tidak termasuk dalam struktur kebutuhan.

Kebudayaan juga berperan dalam melihat kesamaan. Jika dilihat dari kekeyaan, maka orang membagi masyarakat pada dua kelompok: orang kaya dan orang miskin. Dan jika dilihat dari sisi pendidikan, ada dua pengelompokan, yaitu orang terdidik dan orang tidak terdidik. Pengelompokan yang kultural erat sekali kaitannya dengan label, yang kita beri label yang sama cendrung dipersepsi sama. Contoh dengan label “pribumi” dan "non pribumi”, kita mengorganisasikan Cina, India, Arab, Jepang dan Amerika pada kelompok yang sama. (Jalaluddin Rahmat, 2007:5)

Demikianlah uraian dari sensasi dan persepsi, stimuli yang ditangkap oleh indra dipersepsi menjadi informasi, dan kemudian disimpan didalam memori.

\section{Penutup}

Setiap manusia mengalami sensasi dan kemudian timbul persepsi. Allah memberi kita alat-alat indra untuk bisa menjaga dirinya dan mempertahankan kehidupannya. proses sensasi ini diartikan sebagai alat penerima (reseptor) jadi apapun yang dirasakan oleh alat-alat indera kita, maka sensasilah yang menjadi alat penerima apa yang dirasakan oleh alat indera kita. Dan kemudian timbul lah "pemahaman" atau kita dapat "menyimpulkan" dari rangsang tersebut sehingga terjadilah persepsi.Prosespersepsi didahului dengan proses penerimaan stimulus pada reseptor, yaitu indera. Fungsi indera manusia sendiri tidak langsung berfungsi setelah ia lahir, akan tetapi ia akan berfungsi sejalan dengan perkembangan fisiknya. 


\section{DAFTAR KEPUSTAKAAN}

Mubarok,Achmad,Psikologi Dakwah, Jakarta: Pustaka Firdaus, 2008

Mustafa Al-Maragi, Ahmad, Tafsir Al-Maragi, Jus XII, Semarang: Karya Toha Putra Semarang, 1993

Rahman Shaleh,Abdul,Psikologi, Jakarta : Kencana Prenada Media Group, 2008

Rahmat,Jalaluddin Psikologi Komunikasi, Bandung: Remaja Rosdakarya, 2007

Shihab,M. Quraish,Tafsir Al-Misbah, jakarta:Lentera Hati, 2002

Yusuf Ali,Abdullah,Tafsir Yusuf Ali, Bogor : Pustaka Litera AntarNusa, 2009 